\title{
COMPARISON OF SOME RAPID TECHNIQUES USED FOR DIAGNOSIS OF BRUCELLOSIS OF ABORTED COWS COMPARED WITH CONVENTIAL METHOD
}

\author{
ABOU GAZIA, K.A.; EMAN, SH. RAMADAN and MONA M. SOBHY \\ Dept. of Reproductive diseases, ARRI, ARC, Giza, Egypt. \\ Email: khalidabougazia@yahoo.com
}

\section{ABSTRACT}

Received at:21/12/2013

Accepted: 20/2/2014
A total of 158 specimens of uterine discharges and lochia were collected from aborted cows of different localities in Egypt. The blood samples of the same aborted cows were also collected for serological tests. The bacteriological method was applied for isolation of Brucella organisms from 102 uterine discharges and 56 lochia of aborted cows. Primary inoculation was done on Brucella agar plates. The plates were incubated in the presence of $5 \% \mathrm{CO}_{2}$ in Carbon dioxide incubator for 72-120 hrs. The isolates were initially recognized on the basis of their cultural and morphological features and biochemical identification. DOT-ELISA was applied on the colonies plates for detection of Brucella microorganisms in the aborted materials. The direct fluorescent antibody test (DFAT) was applied on the specimens of uterine discharges and lochia. Samples were coated on the slides as antigens, then Brucella specific antibodies labelled with a fluorescein conjugate were added and examined under the fluorescent microscope. The applied serological tests in this study were Rose Bengal Test (RBT), Standard Tube Agglutination Test (SAT), Rivanol Test (RT) and Enzyme Linked Immunosorbant Assay (ELISA) test. The rate of isolation of Brucella melitensis (B. melitensis) from aborted cows was 7.59\% from 12 isolates; $7.84 \%$ from 8 uterine discharges and $7.14 \%$ from 4 lochia by cultural bacteriological method and Dot-ELISA. The result of DFAT were $25(15.82 \%)$ positive; $16(15.69 \%)$ from uterine discharges and $9(16.07 \%)$ from lochia. The results of serological tests on the serum samples were 64 (40.5)\%), 58 (36.71\%), 55 (34.81\%) and $66(41.77 \%)$ positive results for RBT, SAT, RT and ELISA respectively. Finally, we concluded that in order to eradicate and control brucellosis, we must apply a good surveillance reliable diagnostic test. The practical serological diagnosis must be based on screening test of high sensitivity followed by a confirmatory test as ELISA test of high specificity. A combination of serological test with FAT is usually needed for diagnosis of Brucella organisms in aborted cases.

Keywords: Rapid techniques, Brucellosis, Cows.

\section{INTRODUCTION}

Brucella has a significant economic impact on our livestock business. It has severe consequence on production of cattle that influences two of the greatest infertility and sterility problems, (Parker, 2003).

Brucellosis is a highly infectious bacterial disease that mainly affects cattle, sheep, pigs and goats. The organism causing brucellosis primarily infects the reproductive organs and thrives in the uterus of pregnant animals, often leading to late abortion (OIE 2001). The organism can remain undetected for prolonged periods as there are no clinical signs until abortion occurs (AHVLA, 2013).

Bovine brucellosis is the best known and most controversial infection of the bovine reproductive system. It is one of the core profiles of economic consideration in livestock production enterprises since loss of calf due to abortion and its squeal lead to infertility (Verma et al., 2000).

Brucellosis infection of cattle causes abortion or premature calving of recently infected animals, the foetus, placenta and uterine fluid contain large quantities of Brucella organisms which can infect other animal coming into contact with an infected animal around the time of calving (Nielsen et al., 2005).

The gold standard technique for diagnosis of brucellosis is isolation and identification of the causative bacterium Brucella species. Isolation of Brucella organisms requires a high secured laboratory facilities (biological containment level 3), an extended time for results, highly skilled personnel and hazardous procedure. Brucellosis is generally diagnosed by detection of antibodies in serum or other body fluids. Subsequently, various modification of agglutination test and numerous 
other tests have been developed to increase test accuracy (Nielsen and Yu, 2010).

Brucellosis was firstly diagnosed by using a simple tube agglutination test by Wright and Smith (1897). The other tests have been developed to increase test sensitivity. However no test is $100 \%$ accurate. So, generally serological diagnosis consists of testing sera by several tests, usually as screening test of high sensitivity followed by a confirmatory test of high specificity (Nielsen et al., 2005).

The present study was contemplated to reveal some rapid diagnostic techniques used for diagnosis of brucellosis of aborted cows as DFAT and DOTELISA compared with convential method

\section{MATERIALS and METHODS}

In the present study a total of 158 specimens were collected from aborted cows of different farms in Egypt (102 uterine discharges and 56 lochia). Also 158 blood samples of the same aborted cows were collected for serological tests.

The conventional bacteriological methods (Alton et al., 1988) were applied for isolation and identification of Brucella organisms from the all specimens.

Primary inoculation was done on sheep blood agar plates in duplicate by directly streaking the swabs to be cultivated. The plates were incubated at $37^{\circ} \mathrm{C}$ in the presence of $5 \% \mathrm{CO}_{2}$ in Carbon dioxide incubator for $72-120 \mathrm{hrs}$. The isolates were initially recognized on the basis of their cultural and morphological features. They were also biochemically characterized as described by (Carter and Cole, 1995).

DOT-ELISA was applied on the colonies plates for detection of Brucella microorganisms in the aborted materials as described by (Nielsen et al., 2004).

Direct Florescence Antibody Technique (DFAT) was applied on the specimens of uterine discharges and lochia. Samples coated on the slides as antigens and then Brucella_specific antibodies labeled with a fluorescein conjugate were added (Nicoletti and Tanya, 1993).

The serological tests applied on these studies were Rose Bengal tset (RBT), Standerd Tube agglutination test (SAT), Rivanol test (RT) and Enzyme linked Immunoasorbant Assay (ELISA) according to (Nielsen, 2002).

\section{RESULTS}

From 102 uterine discharge samples only 8 brucella isolates could be identified, also 4 brucella isolates could be identified from 56 lochia samples, but when we used DFAT on uterine discharge and lochia gave 25 positive brucella cases.

Serological test applied on serum obtained from 158 blood samples showed better detection of brucella antibody by ELISA 66 sample than Rose Bengal 58 positive sample.

Table 1: Brucella isolates encountered from aborted cows by culture.

\begin{tabular}{cccc}
\hline Type of samples & No. of samples & Brucella isolates* & \% of isolates \\
\hline Uterine discharges & 102 & 8 & $7.84 \%$ \\
Lochia & 56 & 4 & $7.14 \%$ \\
\hline Total & 158 & 12 & $7.59 \%$ \\
\hline
\end{tabular}

* based on cultural, morphological and biochemical features.

Table 2: The incidence of Brucella in samples of aborted cows by DFAT and Dot ELISA.

\begin{tabular}{cccc}
\hline Type of samples & No. of samples & Positive samples by DFAT & Positive samples by Dot ELISA \\
\hline Uterine Discharges & 102 & 16 & 8 \\
Lochias & 56 & $(15.69 \%)$ & $(7.84 \%)$ \\
& & 9 & 4 \\
Total & 158 & $(16.07 \%)$ & $(7.14 \%)$ \\
\hline
\end{tabular}


Table 3: The prevalence of Brucella in serum samples of aborted cows by serological test.

\begin{tabular}{cccccc}
\hline \multirow{2}{*}{ Type of samples } & \multirow{2}{*}{ No. of samples } & \multicolumn{4}{c}{ Serological Tests } \\
\cline { 3 - 6 } & & RBT & SAT & RT & ELISA \\
\hline \multirow{2}{*}{ Serum } & 158 & 64 & 58 & 55 & 66 \\
& & $(40.51 \%)$ & $(36.71 \%)$ & $(34.81 \%)$ & $(41.77 \%)$ \\
\hline
\end{tabular}

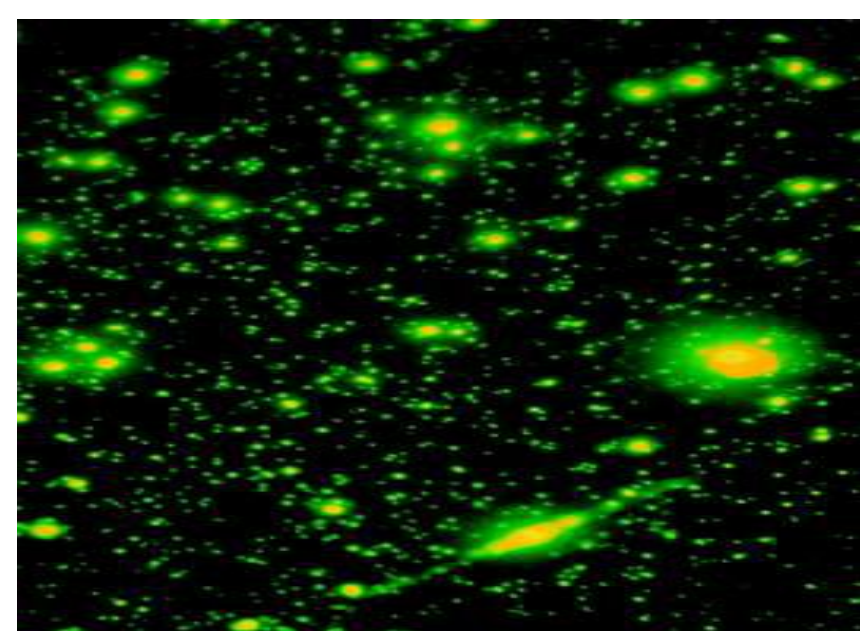

Fig.1: Positive DFAT applied on lochia of aborted cow.

\section{DISCUSSION}

Brucellosis remains a major worldwide zoontic disease (Cutler and Whatmore, 2003). It is a bacterial disaease of global importance that may affect different mammals. The disease primarily affects the reproductive system with concomitant loss in productivity of animals (Young, 1995).

Brucellosis is considered as an emerging problem in developing countries where there is an increasing incidence of B. melitensis in cattle (Corbel, 1997). The organisms survive within the environment for prolonged periods (Moreno and Gorvel, 2004). Interaction with placental trophoblasts suggests that the ability to acquire iron is vital as the Brucella enter their acute replicative stage within the placental disruption resulting in fetal loss or birth of weak and/or infected off spring (Eschenbrenner et al., 2002 and Cutler et al., 2005).

The accurate diagnosis of brucellosis in any species goes straight forward but may be very difficult in some cases (Nielsen and $\mathrm{Yu}, 2010$ ). Brucella diagnostic tests were developed based on agglutination methods. These assays have been played with problems of both sensitivity and specificity (Alton et al., 1988 and Nielsen, 2002).

Diagnosis of brucella infection can be made by isolation and identification of the organisms by convential methods (Bercovich, 2000). In the present study, the rate of isolation of B.melitensis from aborted cows was 12 isolates; 8 from uterine discharges and 4 from lochia by cultural bacteriological method and Dot- ELISA (Table, 1 \& 2). These findings agree with (Zowghi and Ebadi 1988), that all the isolates of brucella encountered in this study were identified by biochemical tests as described by (Carter and Cole, 1995).

The obtained results revealed Brucella positive by direct fluorescent antibody test applied through specific binding of antibody to the provide antigen conjugated with fluorescein conjugate. The results were 25positive cases of DFAT; 16 from uterine discharges and 9 from lochias. These findings coincide with (Samartino et al., 1999) and (Bahn and Nockler 2005). The higher incidence rate of Brucella organisms was done by DFAT which is a simple, rapid diagnostic test, relatively inexpensive and accurate (Nielsen et al., 2004).

Serodiagnonostic methods for brucellosis have primarily been based on serology with lipopolysaccharides (LPS) from smooth strains producing greatest immunological response (Kittelberger et al., 1997). In this study, different serological tests were applied on the serum samples; RBT gave 64, SAT gave 58 RT gave 55 and ELISA test gave 66 positive results (Table, 3). These findings agreed with (Verma et al., 2000 and Nielsen 
et al., 2005). The higher positivity of ELISA test generally has very high sensitivity and excellent screening assays for diagnosis of brucella especially in individual animal test of serum (Wright et al., 1997 and Gall et al., 2001 and McGiven et al., 2003).

\section{CONCLUSION}

Finally, we conclude that in order to eradicate and control brucellosis, we must apply good surveillance reliable diagnostic test. The practical serological diagnosis must be based on screening test of high sensitivity followed by a confirmatory test as ELISA test of high specificity. A combination of serological test with DFAT is usually needed for diagnosis of brucella organisms in aborted cases.

\section{REFERENCES}

AHVLA (2013): Animal Health and Veterinary Laboratories Agency, London, England. (C) Crown Copyright.

Alton, G.G.; Jones, L.M.; Angus, R.D. and Verger, J.M. (1988): Techniques for brucellosis laboratory. Inst. Nat. de Res. Agronomique, Paris, France.

Bahn, P. and Nockler, K. (2005): Validation of the fluorescence Polarization assay (FPA) for the serological diagnosis of brucellosis. Berl. Tierarztl. Wochenschr. 118: 372-6.

Bercovich, Z. (2000): The use of skin delayed-type hypersensitivity as an adjunct test to diagnose brucellosis in cattle: a review. Vet Q 22, 123-130

Carter, G.R. and Cole, J.R. (1995): Diagnostic procedures in veterinary bacteriology and mycology. $6^{\text {th }}$ Ed. Academic Press Inc. California.

Corbel, M. (1997): Brucellosis: an overview. Emerg Infect Dis 3, 213-221.

Cutler, S. and Whatmore, A. (2003): Progress in understanding brucellosis. Vet. Rec. 153, 641-642.

Cutler, S.J.; Whatmore, N.J. and Commander, N.J. (2005): Brucellosis - new aspects of an old disease. J. App. Microbiol. Volume 98, Issue 6, p1270-1281.

Eschenbrenner, M.; Wagner, M.A.; Horn, T.A.; Kraycer, J.A.; Mujer, C.V.; Hagius, S.; Elzer, P. and DelVecchio, V.G. (2002): Comparative proteome analysis of Brucella melitensis vaccine strain Rev 1 and a virulent strain, 16 M. J Bacteriol 184, 4962-4970.

Gall, D.; Nielsen, K.; Forbes, L.; Cook, W.; Leclair, D.; Balsevicius, S.; Kelly, L.; Smith, P. and Mallary, M. (2001): Evaluation of the fluorescence polarization assay and comparison to other serological assays for detection of brucellosis in cervids. J. Wildl. Dis., 37: 110-118.
Kittelberger, R.; Reichel, M.P.; Joyce, M.A. and Staak, C. (1997): Serological crossreactivity between Brucella abortus and Yersinia enterocolitica 0: 9. III. Specificity of the in vitro antigen-specific gamma interferon test for bovine brucellosis diagnosis in experimentally Yersinia enterocolitica 0: 9infected cattle. Vet. Microbiol. 57, 361-371.

McGiven, J.; Tucker, J.; Perrett, L.; Stoack, J.; Brew, S. and MacMillan, A. (2003): FPA and cELISA for the detection of antibodies to Brucella abortus in cattle sera and comparison to SAT, CFT and iELISA. J. Immunol. Meth; 278: $171-8$

Moreno, E. and Gorvel, J.-P. (2004): Invasion, intracellular trafficking and replication of Brucella organisms in professional and nonprofessional phagocytes. In Brucella Molecular and Cellular Biology ed. LopesGoni, I. and Moriyon, I. pp. 287-312. Norfolk, UK: Horizon Bioscience.

Nicoletti, P. and Tanya, V. (1993): Comparison of enzyme labelled immunosorbent assay and practical concentration fluorescence immunoassay with standard serologic methods and bacterial culture for detection of brucella sp. infected cows in herds with brucellosis. J. Am. Vet. Med. Assoc.; 202: 1975-7.

Nielsen, K. (2002): Diagnosis of brucellosis by serology. Vet. Microbiol. 90:447-459.

Nielsen, K.; Smith, P.; Conde, S.; Draghi de Benitez, G.; Gall, D.; Halbert, G.; Kenny, K. and Massengill, $\quad$ C. $\quad$ (2004): $\quad$ Rough lipopolysaccharide of Brucella abortus RB51 as a common antigen for serological detection of B. ovis, B. canis, and B. abortus RB51 exposure using indirect enzyme immunoassay and fluorescence polarization assay. J. Immunoassay Immunochem 25, 171-182.

Nielsen, K.; Smith, P.; Yu, W.; Nicoletti, P.; Elzer, P. and Robles, C. (2005): Towards single screening test for brucellosis. Rev. Sci. Tech.; 24: $1027-37$.

Nielsen, $K$. and $Y u$, W.L. (2010): Serological diagnosis of brucellosis. Sc. Biol. Med. Sci. MASA, 1 p: 65-89.

OIE (World organization for animal Health) (2001): Manual of standards for diagnostic tests and vaccines, 4th Ed. OIE, Paris, 957 pp

Parker, R. (2003): Diseases Affecting Reproduction in Beef Cattle. College of Agricultural, Consumer and Environmental Sciences, New Mexico State University.

Samartino, L.; Gall, D.; Gregoret, R. and Nielsen, K. (1999): Validation of enzyme linked immunosorbent assays for the diagnosis of bovine brucellosis. Vet. Microbiol. 70: 193-200. 
Verma, S.; Katoch, R.C.; Sharma, M. and Niagom, P. (2000): Abortions and infertility in livestock due to brucellosis in Himachal Prodesh, India. Vet. Arhiv. 70: 75-82.

Wright, A.E. and Smith, F. (1897): Cited by Morgan, W.J.B. (1967): The serological diagnosis of bovine brucellosis. Vet. Rec., 80: 612-620.

Wright, P.F.; Tounkara, K.; Lelenta, M. and Jeggo, M.H. (1997): International reference standard: antibody standards for the indirect enzymelinked immunosorbent assay. Rev. Sci. Tech., 3: 824-832.

Young, D.A. (1995): Fluorescence Nightingale's fever. Br Med. J. 311, 1697-1700.

Zowghi, E. and Ebadi, A. (1988): Abortions due to Brucella abortion in sheep in Iran. Rev. Scien. Techn. Office. Intentional des. Epizooties, 7: 379-382.

\section{مقارنة بعض الطرق السريعة لتشخيص مرض البروسيلا فى الأبقار المجهضة مع الطريقة التقليدية \\ خالد عبد السمبع ابو جازية ، ابيان شوقت رمضان ، منى محمد صبحى \\ Email: khalidabougazia@yahoo.com}

تم تجميع عدد 158 عينة من أبقار مجهضة اثتنملت على عدد 102 عينة أفرازات رحمية وعدد 56 عينة السائل النفاسى وتم أخذ الخئ

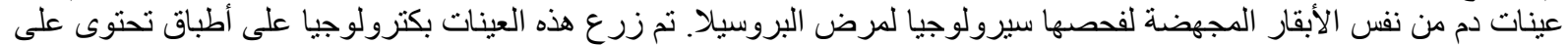

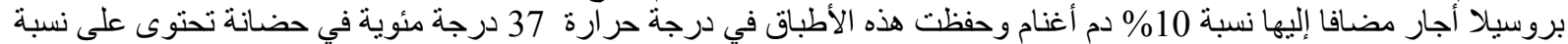

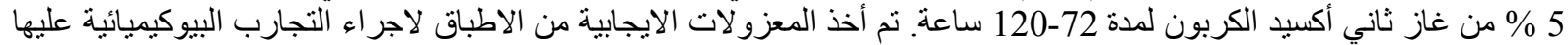

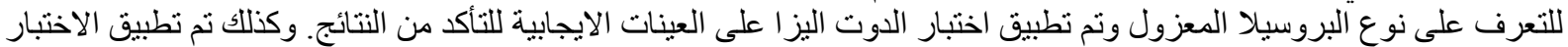

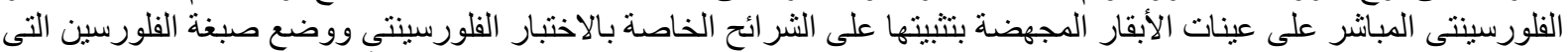

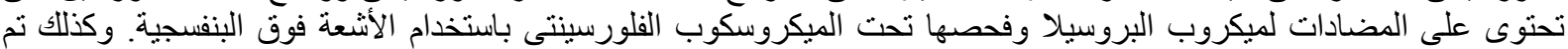

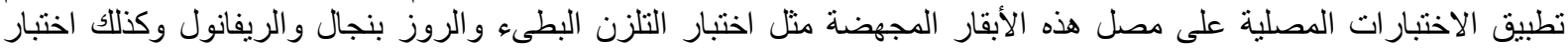

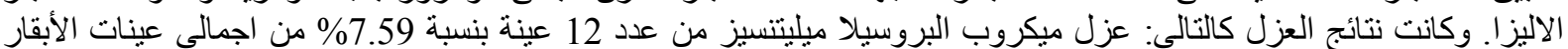

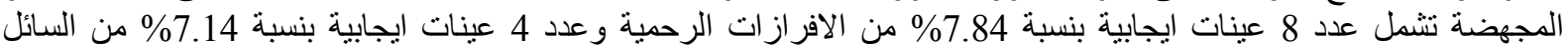

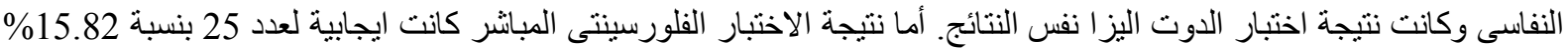

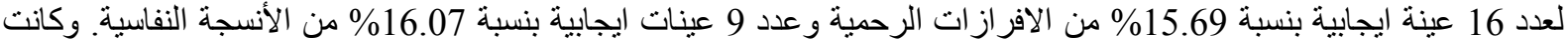

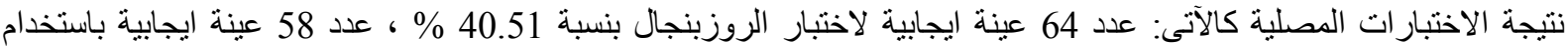

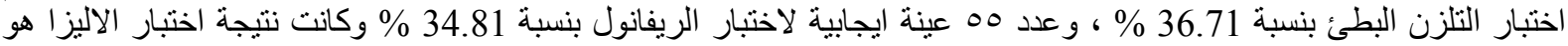

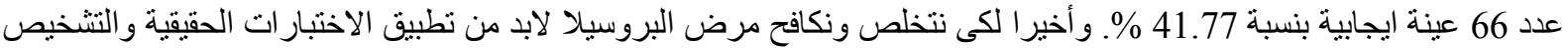

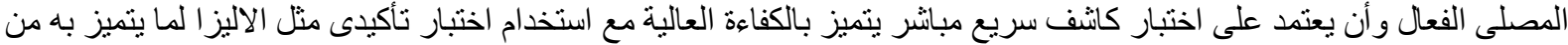

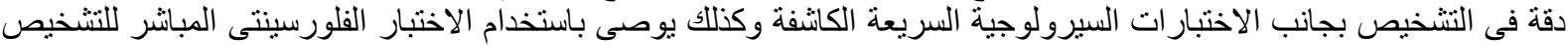
السريع لحالات الاجهاض فى الابقار. 